\title{
Determination of Tramadol in Human Serum by Capillary Electrophoresis with the End-Column Electrochemiluminescence Detection
}

\author{
Caiyun Zhang, Tao Liu, Xiaoli Zhang, Erbao Liu* \\ The School of Chemistry and Materials Science, Shanxi Normal University, Linfen, China \\ Email: *liueb123@163.com
}

Received January 13, 2013; revised February 17, 2013; accepted February 27, 2013

Copyright (C) 2013 Caiyun Zhang et al. This is an open access article distributed under the Creative Commons Attribution License, which permits unrestricted use, distribution, and reproduction in any medium, provided the original work is properly cited.

\begin{abstract}
A capillary electrophoresis (CE) coupled with end-column electrochemiluminescence (ECL) detection method for the analysis of tramadol (TMD) has been investigated. ECL detection was working electrode biased at $1.2 \mathrm{~V}$ in a 20 $\mathrm{mmol} \cdot \mathrm{L}^{-1}$ sodium phosphate buffer $(\mathrm{pH}=8.0)$ containing $5 \mathrm{mmol} \cdot \mathrm{L}^{-1} \mathrm{Ru}(\mathrm{bpy})_{3}^{2+}$ (where bpy $=2,2^{\prime}$-bipyridyl). Linear correlation $(r \geq 0.997)$ between ECL intensity and drug concentration was obtained in the range $3 \times 10^{-4}-6 \times 10^{-6}$ $\mathrm{mol} \cdot \mathrm{L}^{-1}$. The limits of detection (LODs) for tramadol in water was $3.012 \times 10^{-8} \mathrm{~mol} \cdot \mathrm{L}^{-1}(\mathrm{~S} / \mathrm{N}=3)$. The relative standard deviation values on peak size $\left(10^{-5} \mathrm{~mol} \cdot \mathrm{L}^{-1}\right.$ level $)$ and migration time for the tramadol were $4.58 \%$ and $1.39 \%(n=10)$, respectively. Applicability of the CE-ECL method to the analysis of human serum spiked with tramadol was examined.
\end{abstract}

Keywords: Capillary Electrophoresis; Electrochemiluminescence; Tramadol Hydrochloride; Human Serum

\section{Introduction}

Tramadol (Figure 1) hydrochloride is a new category of non-morphine analgesic drugs, which can alleviate the ache because of bone fracture or each technique, the mild cancer. Therefore, a sensitive method to determine tramadol at low level is of considerable for pharmacokinetic and clinical studies. In these methods, the ultraviolet (UV) [1], high-performance liquid chromatography (HPLC) [2], capillary electrophoresis gas chromatography (CEGC), and bolivian carbon electrode voltammetry are commonly used. But these methods need preconcentration before determination because of lacking high sensitive detector.

Capillary electrophoresis (CE) had attracted much attention and became an important and powerful analytical tool in liquid separation and detection areas [3] including the analysis of inorganic ions, organic molecules, clinic and pharmaceutical fields [4]. CE technique has advantages of minimal sample volume, high separation efficiency, relatively short analysis time and low instrumental cost [5]. These advantages make $\mathrm{CE}$ an alternative to HPLC. With this method, tramadol is detected with UV [6-7], MS [8] or LIF [9]. Whereas, either low sensitivity

${ }^{*}$ Corresponding author. as UV, or complicated equipment and high price of detector as LIF and MS limit related practical application.

CE coupled with ECL using $\mathrm{Ru}(\mathrm{bpy})_{3}^{2+}$ has been studied in recent years. CE-ECL offers the merits with enhanced sensitivity, improved selectivity, possible micromation and integration and reduced cost. Because of intrinsic characters of ECL of Ru(bpy $)_{3}^{2+}$, it shows especially high sensitivity for tertiary amines [10], and it is used to detect amino acid, peptides and $\beta$-blockers [11-16] for CE. Wang et al. [17] ever have used CE-ECL endcolumn for simultaneous determination of tramadol and lidocaine in urine. In our research, serum (after centri-

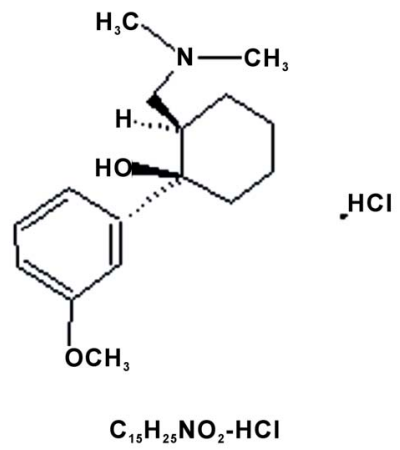

Figure 1. Formulae of tramadol. 
fuged plasma) as sample. On the other hand, plasma circulation is a relative obturate system compared with urine metabolism according to the quantity of water that intake by different individuals. Using CE-ECL method to determine tramadol in serum reflects tramadol metabolism more geuine. Therefore, it is necessary to develop a more reproducible, more precise, selective and more simple method to study tramadol in human serum.

In this paper, a simple, fast, sensitive and more selective method for detecting tramadol is presented and successfully used to determine the tramadol contents in human serum sample.

\section{Experimental}

\subsection{Reagents and Chemicals}

All chemicals and reagents used in this experiment were of analytical grade. Tramadol hydrochloride (TMD) was purchased from National Institute for the Control of Pharmaceutical and Biological Products. Tris (2,2'bipyridyl) ruthenium (II) chloride hexahydrate (98\%) was purchased from Sigma-Aldrich Chemical Co. (Milwaukee, WI, USA) and used without further purification. The running buffer was prepared with $\mathrm{Na}_{2} \mathrm{HPO}_{4}$ and $\mathrm{NaH}_{2} \mathrm{PO}_{4}$ at a phosphate concentration of $20 \mathrm{mmol} \cdot \mathrm{L}^{-1}$ and $\mathrm{pH}$ of 8.0. Double-distilled water was prepared by a Milli-Q water purification system (Millipore, Bedford, MA, USA). All solutions were stored in the refrigerator at $4^{\circ} \mathrm{C}$ and filtered through a $0.22 \mu \mathrm{m}$ membrane filter before use.

\subsection{Apparatus}

MPI-A CE-ECL was purchased from Xi'an Remax Electronic Science-Tech Co. (China). The end-column detection cell of CE-ECL was composed of a three-electrode system $(300 \mu \mathrm{m}$ diameter Pt disc as working electrode, $\mathrm{Ag} / \mathrm{AgCl}^{-1}$ electrode as reference electrode, and Pt wire as counter electrode). An uncoated fused-silica capillary ( $25 \mu \mathrm{m}$ I.D., $360 \mu \mathrm{m}$ O.D.) with the length of $40 \mathrm{~cm}$ from Yongnian Optical Conductive Fiber Plant (Hebei, China) was set between two buffer reservoirs and electrophoresis was driven by the high potential apparatus. Electrochemical analyzer was adapted to constant potential control. Multi-channel data acquirement and analysis apparatus was employed to collect the intensity of the electrogenerated chemiluminescence.

\subsection{Preparation of Standard Solutions}

The stock solution of $1 \mathrm{mmol} \cdot \mathrm{L}^{-1}$ tramadol hydrochloride was prepared by dissolving $23.3 \mathrm{mg}$ tramadol hydrochloride in $50 \mathrm{~mL}$ water and stored at $4^{\circ} \mathrm{C}$ in a refrigerator. Before use, the stock solution is diluted with water to prepare standard solutions with a series of concen- trations for the construction of calibration curve, the study of reproducibility and the study of recovery.

\section{Results and Discussion}

\subsection{Cyclic Voltammograms of $\operatorname{Ru}(\mathrm{bpy})_{3}^{2+}$ and Tramadol Hydrochloride}

We studied the ECL behaviors of $\mathrm{Ru}(\mathrm{bpy})_{3}^{2+}$ and TMD at the Pt electrode. As shown in Figure 2, there was no ECL intensity at Pt electrode in $50 \mathrm{mmol} \cdot \mathrm{L}^{-1}$ phosphate buffer with $5 \mathrm{mmol} \cdot \mathrm{L}^{-1} \mathrm{Ru}(\text { bpy })_{3}^{2+}$ (curve a). When $10^{-4}$ $\mathrm{mol} \cdot \mathrm{L}^{-1}$ TMD was added, the ECL intensity increased rapidly from 1.0 to $1.3 \mathrm{~V}$ (curve b) and reached a maximum at $1.17 \mathrm{~V}$. This accorded with the oxidation potential of $\mathrm{Ru}(\mathrm{bpy})_{3}^{2+}[18]$, which indicated that the oxidation of $\mathrm{Ru}(\mathrm{bpy})_{3}^{2+}$ played an important role on the TMD-ECL reaction.

\subsection{CE-ECL Optimization}

We studied the operating parameters on the TMD determination, such as the detection potential, injection voltage, injection time and buffer conditions as follows.

\subsubsection{Effect of Hydrodynamic Voltammograms (HDVs)}

The effect of detection potential on the ECL intensity of TMD was investigated as shown in hydrodynamic voltammograms (HDVs) Figure 3. The ECL intensity was not reached maximum when the detection potential was lower than $1.0 \mathrm{~V}$ because $\mathrm{Ru}(\mathrm{bpy})_{3}^{2+}$ was not oxidized on the working electrode totally. When the potential was stepped from 1.0 to $1.3 \mathrm{~V}$, the ECL intensity of TMD increased accordingly, and reached a maximum at $1.20 \mathrm{~V}$, after that the signal decreased slightly. So $1.20 \mathrm{~V}$ (versus $\mathrm{Ag} / \mathrm{AgCl}^{-1}$ ) was selected as the ECL optimum detection potential.

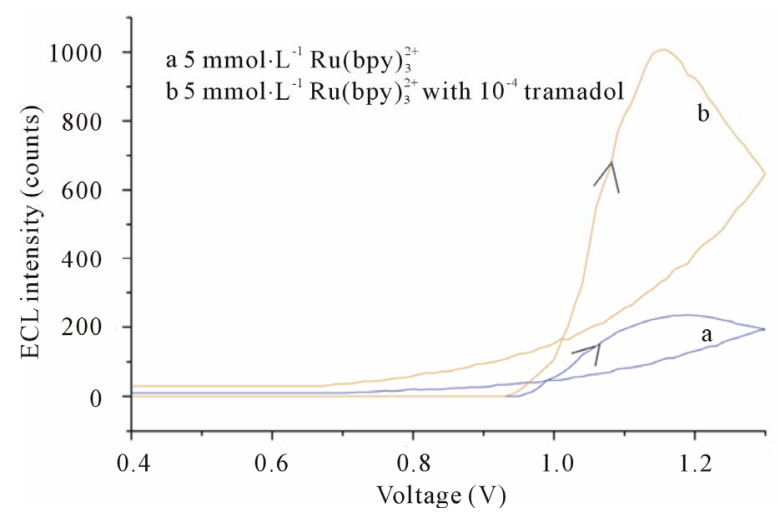

Figure 2. Dependence of the ECL intensity on applied voltage curve. Conditions: $5 \mathrm{mmol} \cdot \mathrm{L}^{-1} \mathrm{Ru}(\mathrm{bpy})_{3}^{2+}$ without (a) or with (b) $3 \times 10^{-4} \mathrm{~mol} \cdot \mathrm{L}^{-1}$ tramadol hydrochlorid. 50 $\mathrm{mmol} \cdot \mathrm{L}^{-1}$ phosphate buffer at $\mathrm{pH} 7.67$ in the detection cell. 


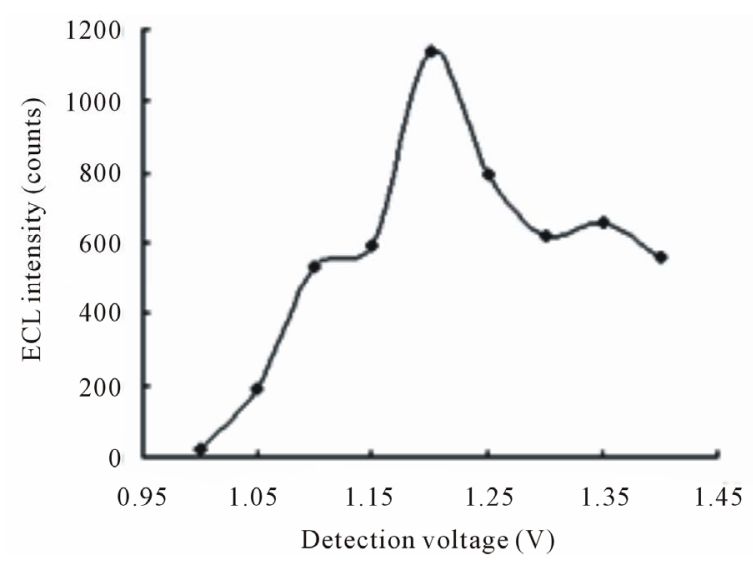

Figure 3. Dependence of the ECL intensity on the detection potential. Conditions: $3.108 \times 10^{-4} \mathrm{~mol} \cdot \mathrm{L}^{-1}$ tramadol hydrochlorid solution, $20 \mathrm{mmol} \cdot \mathrm{L}^{-1}$ phosphate buffer at $\mathrm{pH}$ 7.80, $5 \mathrm{mmol} \cdot \mathrm{L}^{-1} \mathrm{Ru}(\mathrm{bpy})_{3}^{2+}$ in the detection cell, electrokinetic injection $10 \mathrm{~s} \times 10 \mathrm{kV}$.

\subsubsection{PH of Running Buffer}

The $\mathrm{pH}$ of detection buffer has a significant effect on the ECL response. The previous work indicated that $\mathrm{Ru}(\text { bpy })_{3}^{2+}$ has a good ECL efficiency in a weak basic solution because of the deprotonation of the amine species to form a reducing free radical intermediate and the reaction between radical intermediate and tramadol species [19-24]. Also, the $\mathrm{pH}$ of separation buffer influences electroosmotic flow (EOF) and the analyte ionization and thus, the separation efficiency. Moreover, if the $\mathrm{pH}$ value of separation buffer is different from that of detection buffer, a $\mathrm{pH}$ gradient will be noticed along the capillary; so, to eliminate the effect of the difference between detection buffer and separation buffer, two buffers with same $\mathrm{pH}$ were used. Figure 4 gives the effect of buffer $\mathrm{pH}$ on the detection sensitivity and migration time. The highest ECL intensity of tramadol was at $\mathrm{pH}$ 8.0. With increasing $\mathrm{pH}$ of the buffer, the eletroosmotic flow inside capillary increased remarkably, and the migration time increase gradually. To maintain good sensitivity and a suitable analysis time, both the detection buffer and separation buffer with $\mathrm{pH} 8.0$ were used.

\subsubsection{Effect of Injection System}

We investigated effects of injection voltage and injection time on the ECL intensity of TMD, respectively. The ECL intensity increased with higher injection voltage was almost proportional to voltage in the range from 2 to $18 \mathrm{kV}$ shown in Figure 5. When the voltage was higher than $10 \mathrm{kV}$, the ECL intensity increased slowly, moreover, the higher injection voltage also led the column efficiency falling. Hence, the $10 \mathrm{kV}$ was chosen.

The injection time also affected the detection at the intensity voltage of $10 \mathrm{kV}$. The Figure 6 indicated when injection time changed from 4 to $18 \mathrm{~s}$, the ECL signal

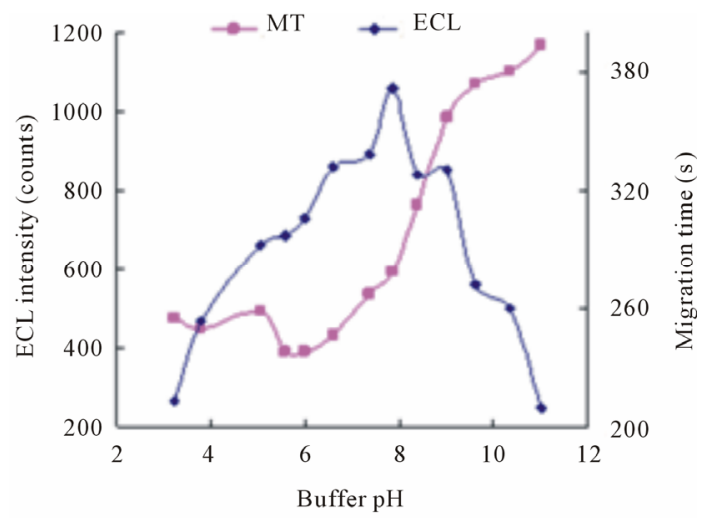

Figure 4. Effect of the buffer pH on ECL intensity $(\diamond)$ and migration time (a). Conditions: $2.1756 \times 10^{-5} \mathrm{~mol} \cdot \mathrm{L}^{-1}$ tramadol hydrochlorid, $5 \mathrm{mmol} \cdot \mathrm{L}^{-1} \mathrm{Ru}(\mathrm{bpy})_{3}^{2+}, 20 \mathrm{mmol} \cdot \mathrm{L}^{-1}$ phosphate buffer, detection potential $1.20 \mathrm{~V}$, electrokinetic injection $10 \mathrm{~s} \times 10 \mathrm{kV}$.

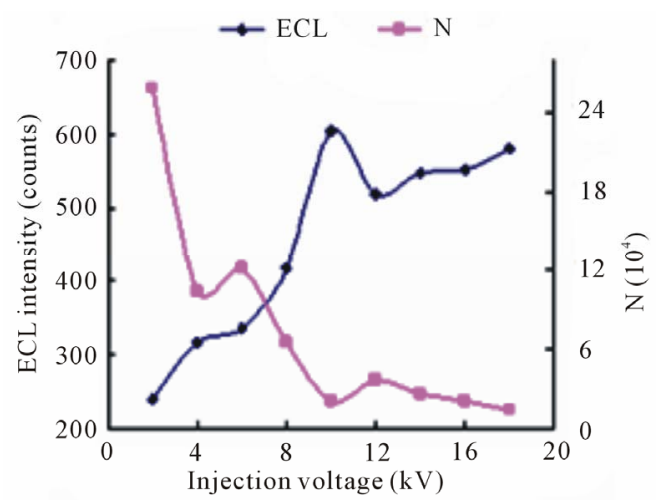

Figure 5. Dependence of the ECL intensity $(\diamond)$ and separation efficiency (a) on the injection voltage. Conditions: phosphate buffer at $\mathrm{pH} 7.80,2.1576 \times 10^{-5} \mathrm{~mol} \cdot \mathrm{L}^{-1}$ tramadol hydrochlorid solution, $5 \mathrm{mmol} \cdot \mathrm{L}^{-1} \operatorname{Ru}(\mathrm{bpy})_{3}^{2+}$, injection time $10 \mathrm{~s}$, detection potential $1.20 \mathrm{~V}$.

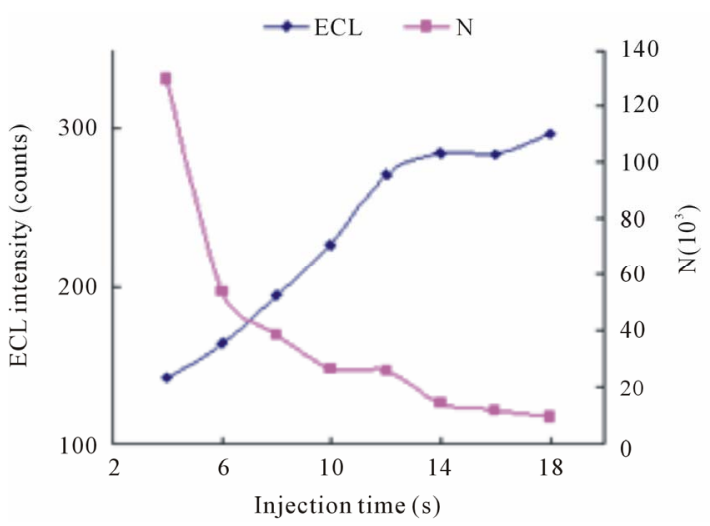

Figure 6. Dependence of the ECL intensity $(\diamond)$ and separation efficiency $(\square)$ on the injection time. Conditions: 2.1576 $\times 10^{-5} \mathrm{~mol} \cdot \mathrm{L}^{-1}$ tramadol hydrochlorid solution, $5 \mathrm{mmol} \cdot \mathrm{L}^{-1}$

$\mathrm{Ru}(\mathrm{bpy})_{3}^{2+}$, phosphate buffer at pH 7.80 , injection voltage $10 \mathrm{kV}$, detection potential $1.20 \mathrm{~V}$. 
increased proportionally, but the low column efficiency occurred. Therefore, $10 \mathrm{~s}$ was selected as optimum injection condition.

\subsubsection{Concentration of $\mathrm{Ru}(\mathrm{bpy})_{3}^{2+}$}

$\mathrm{Ru}(\mathrm{bpy})_{3}^{2+}$ was post-column added in our work. The ECL reaction was expected to occur when tramadol met $\mathrm{Ru}(\text { bpy })_{3}^{2+}$ at the electrode surface. The concentration of $\mathrm{Ru}(\mathrm{bpy})_{3}^{2+}$ may exert an effect on the detection sensitivity. Figure 7 shows the ECL intensity changes as a function of $\mathrm{Ru}(\mathrm{bpy})_{3}^{2+}$ concentration. Kept tramadol concentration at a constant value of $2.15 \times 10^{-5} \mathrm{~mol} \cdot \mathrm{L}^{-1}$ determined the ECL intensity when $\mathrm{Ru}(\mathrm{bpy})_{3}^{2+}$ concentration was changed. In the range of $3-10 \mathrm{mmol} \cdot \mathrm{L}^{-1}$ $\mathrm{Ru}(\mathrm{bpy})_{3}^{2+}, \mathrm{ECL}$ intensity rose steadily with an increase of $\mathrm{Ru}(\mathrm{bpy})_{3}^{2+}$ concentration and reached the maximum when the concentration of $\mathrm{Ru}(\mathrm{bpy})_{3}^{2+}$ was $5 \mathrm{mmol} \cdot \mathrm{L}^{-1}$. Beyond $5 \mathrm{mmol} \cdot \mathrm{L}^{-1}$, the ECL intensity was not enhanced and distinct minished. Thus, $5 \mathrm{mmol} \cdot \mathrm{L}^{-1} \mathrm{Ru}(\mathrm{bpy})_{3}^{2+}$ was chosen for further experiment in light of sensitivity and stability.

\subsubsection{Analytical Performance of the Present CE-ECL}

Under the optimized conditions, detection voltage of 1.2 $\mathrm{V}$, buffer at $\mathrm{pH} 8.0$, electrokinetic injection for $10 \mathrm{~s}$ at 10 $\mathrm{kV}$, and $5 \mathrm{mmol} \cdot \mathrm{L}^{-1} \mathrm{Ru}(\text { bpy })_{3}^{2+}$ in the detection cell, the reproducibility of the method was tested by consecutive injection of tramadol standard solution of $10^{-4}$ and $10^{-5}$ $\mathrm{mol} \cdot \mathrm{L}^{-1}(\mathrm{n}=10)$. The R.S.D. values of ECL intensity and migration time were $4.58 \%$ and $1.39 \%$ for $10^{-4} \mathrm{~mol} \cdot \mathrm{L}^{-1}$ and $4.55 \%$ and $0.72 \%$ for $10^{-5} \mathrm{~mol} \cdot \mathrm{L}^{-1}$, respectively. A series of standard solutions with different concentration was tested to determine the linearity. Regression equation is $\mathrm{Y}=737.9 \mathrm{x}+64.591(\mathrm{n}=12)$. Correlation coefficient is 0.9973 . The calibration curve obtained exhibited satisfactory linear behavior over the concentration ranging from $6 \times 10^{-6} \mathrm{~mol} \cdot \mathrm{L}^{-1}$ to $3 \times 10^{-4} \mathrm{~mol} \cdot \mathrm{L}^{-1}$ with a detection limit of $3.012 \times 10^{-8} \mathrm{~mol} \cdot \mathrm{L}^{-1}(\mathrm{~S} / \mathrm{N}=3)$. Compared with other optical detection methods showed in Table 1, the present method has the advantages of selectivity, sensitivity, reproducibility, linearity and small sample.

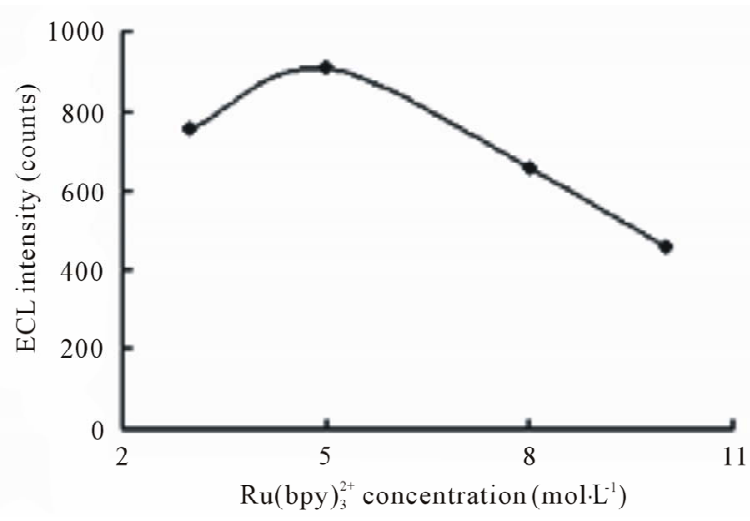

Figure 7. Effect of $\operatorname{Ru}(\mathrm{bpy})_{3}^{2+}$ concentration on ECL intensity. Conditions: $2.1576 \times 10^{-5} \mathrm{~mol} \cdot \mathrm{L}^{-1}$ tramadol hydrochlorid solution; $20 \mathrm{mmol} \cdot \mathrm{L}^{-1}$ running buffer at $\mathrm{pH} 7.80 ; 50$ $\mathbf{m m o l} \cdot \mathrm{L}^{-1}$ phosphate buffer in the detection cell; electrokinetic injection $10 \mathrm{~s} \times 10 \mathrm{kV}$.

\section{Applications}

The proposed CE-ECL method was employed for the determination of TMD in human serum sample. Two healthy young volunteers' blood samples were collected and immediately centrifuged to get the serum. Before use, the serum samples were diluted 10 -fold with doubledistilled water and filtered with $0.22 \mu \mathrm{m}$ membrane. Analyzed serum samples in the same optimized conditions. Figure 8(A-a) and Figure 8(B-a) were the electropherograms of the blank volunteer $A$ serum and the blank volunteer B serum, respectively. The obvious peak variety reveals the individual differences.

Added $10 \mu \mathrm{mol} \cdot \mathrm{L}^{-1} \mathrm{TMD}$ to the diluted serums, respectively, and determined them in the optimized conditions by CE-ECL method. A similar peak occurred in Figure 8(A-b) and Figure 8(B-b). The tramadol signal occurred at $300 \mathrm{~s}$. The recoveries of tramadol in VA and VB serum sample at different concentrations were $93 \%$ $81 \%$ and $89 \%-76 \%$, respectively. The R.S.D of ECL peak intensity was less than $7.0 \%$. Results showed in Table 2. Further, the changes of TMD in serum with time were shown in Figure 9(A) and Figure 9(B) for 2

Table 1. Comparison of analytical performances of the previously reported methods with the proposed method.

\begin{tabular}{|c|c|c|c|}
\hline Methods & Linear range & Detection limit & Reference \\
\hline High-performance liquid chromatographic & $3.33 \times 10^{-8}-6.67 \times 10^{-6} \mathrm{~mol} \cdot \mathrm{L}^{-1}$ & $3.33 \times 10^{-8} \mathrm{~mol} \cdot \mathrm{L}^{-1}$ & {$[25]$} \\
\hline Development and validation of a rapid HPLC method & $8.34 \times 10^{-9}-1.67 \times 10^{-6} \mathrm{~mol} \cdot \mathrm{L}^{-1}$ & $8.34 \times 10^{-9} \mathrm{~mol} \cdot \mathrm{L}^{-1}$ & {$[26]$} \\
\hline Solid phase extraction and gas chromato graphy-mass & Not reported & $3.33 \times 10^{-8} \mathrm{~mol} \cdot \mathrm{L}^{-1}$ & {$[27]$} \\
\hline Electrophoretic microchip with electrochemiluminescence detector & $5.0 \times 10^{-5}-2.5 \times 10^{-3} \mathrm{~mol} \cdot \mathrm{L}^{-1}$ & $2.5 \times 10^{-5} \mathrm{~mol} \cdot \mathrm{L}^{-1}$ & {$[28]$} \\
\hline Improved liquid chromatographic method & Not reported & $8.34 \times 10^{-9} \mathrm{~mol} \cdot \mathrm{L}^{-1}$ & {$[29]$} \\
\hline Electrochemical methods & $1.5 \times 10^{-7}-7.5 \times 10^{-7} \mathrm{~mol} \cdot \mathrm{L}^{-1}$ & $1.7 \times 10^{-6} \mathrm{~mol} \cdot \mathrm{L}^{-1}$ & {$[30]$} \\
\hline Capillary electrophoresis with electrochemiluminescence detection & $1.0 \times 10^{-4}-1.0 \times 10^{-7} \mathrm{~mol} \cdot \mathrm{L}^{-1}$ & $6.0 \times 10^{-8} \mathrm{~mol} \cdot \mathrm{L}^{-1}$ & {$[17]$} \\
\hline
\end{tabular}




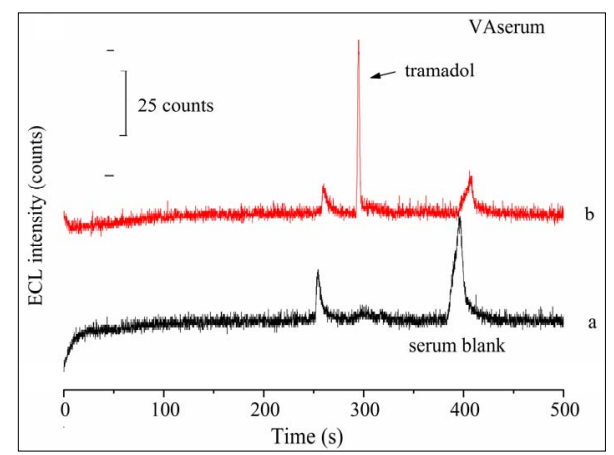

(A)

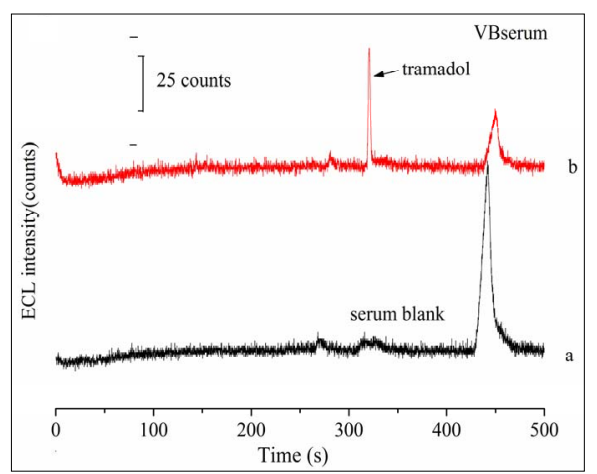

(B)

Figure 8. Typical electropherograms of: (a) 1:10 diluted blank volunteer (A) serum or volunteer (B) serum sample; (b) $10 \mu \mathrm{mol} \cdot \mathrm{L}^{-1} \mathrm{TMD}$ was spiked to a. Conditions: detection voltage $1.2 \mathrm{~V}$, buffer at $\mathrm{pH} \mathrm{8.0}$, electrokinetic injection for $10 \mathrm{~s}$ at $10 \mathrm{kV}, 5 \mathrm{mmol} \cdot \mathrm{L}^{-1} \mathrm{Ru}(\mathrm{bpy})_{3}^{2+}$ in the detection cell.

hours, 4 hours and 24 hours, respectively. We can see that there is not any obvious signals variety with the change of time in the range from $2 \mathrm{~h}$ to $4 \mathrm{~h}$ for the two samples. However, after $4 \mathrm{~h}$, the signal reduced greatly. The exact reason remains unclear, but this may be associated with some substances or bacteria in serum sample inducing the decomposition of the tramadol and just so the complex environment induced the change in migration time. According to the above phenomenon we suggest that tramadol stand in hunman serum not more than 24 hours. Determination of tramadol in serum by CEECL was still successes with the advantages of selectivity, sensitivity, reproducibility, simple for sample treatment.

\section{Conclusion}

In this paper, the end-column electrochemiluminescence detection with capillary electrophoresis has been used for the determination of TMD as a simple, fast, sensitive and selective method. A wide linear range for TMD with three orders of magnitude, and a detection limit of 0.03 $\mu \mathrm{mol} \cdot \mathrm{L}^{-1}$ were obtained. The proposed method has been triumphantly utilized to analyze TMD in practical sam-
Table 2. Recovery of tramadol in urine and serum samples. Conditions: detection voltage $1.20 \mathrm{~V}$, buffer at $\mathbf{p H} 8.0$, electrokinetic injection for $10 \mathrm{~s}$ at $10 \mathrm{kV}, 5 \mathrm{mmol} \cdot \mathrm{L}^{-1}$ $\operatorname{Ru}(\mathbf{b p y})_{3}^{2+}$ in the detection cell.

\begin{tabular}{cccc}
\hline Sample & $\begin{array}{c}\text { Concentration } \\
\left(\boldsymbol{\mu} \mathbf{m o l} \cdot \mathbf{L}^{-1}\right)\end{array}$ & Recovery $(\%)$ & R.S.D (\%) \\
\hline \multirow{3}{*}{ VA serum } & 1.0 & 93 & 3.3 \\
& 2.5 & 85 & 5.0 \\
& 5.0 & 81 & 5.6 \\
VB serum & 1.5 & 89 & 4.1 \\
& 4.0 & 82 & 5.3 \\
& 6.5 & 76 & 6.8 \\
\hline
\end{tabular}

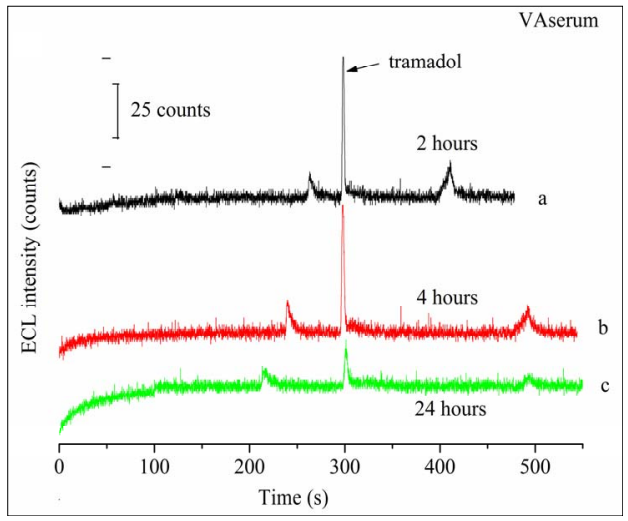

(A)

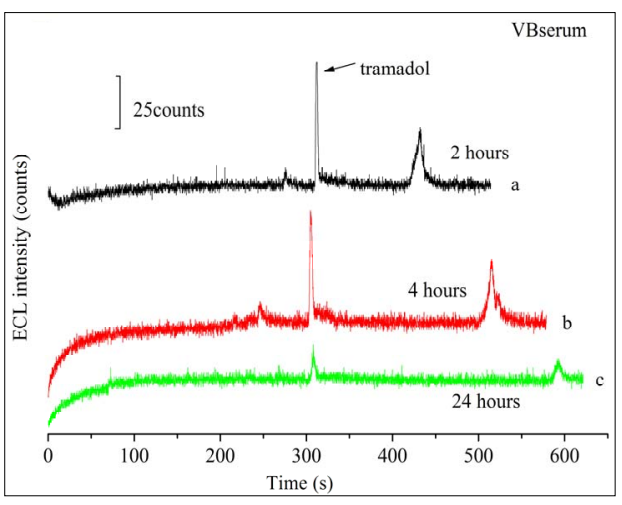

(B)

Figure 9. Dependence of the ECL intensity on the time in volunteer (A) serum and volunteer (B) serum with tramadol solution. Conditions: detection voltage $1.2 \mathrm{~V}$, buffer at $\mathrm{pH}$ 8.0, electrokinetic injection for $10 \mathrm{~s}$ at $10 \mathrm{kV}, 5 \mathrm{mmol} \cdot \mathrm{L}^{-1}$ $\operatorname{Ru}(\text { bpy })_{3}^{2+}$ in the detection cell.

ples and there was no interference, which proves that the proposed method is suitable for clinical analysis.

\section{Acknowledgements}

This project was supported by the Natural Science Foundation of Tianjin, China with Grant No. 08JCYBJC02800 . 


\section{REFERENCES}

[1] C. Lee and Y. Z. Yang and Y. B. Lei, "UV Spectrophotometric Determination of Tramadol Hydrochloride Capsule Content," Liaoning Pharmacy and Clinical Rehedies, Vol. 1, No. 3, 1998, pp. 103-105.

[2] F. Qiu, J. B. Li, H. X. He and Y. D. Zhou, "Determination of Tramadol in Human Plasma by High-Performance Liquid Chromatographic," Chinese Journal of Forensic Medicine, Vol. 18, No. 2, 2003, pp. 96-98.

[3] J. W. Jorgenson and K. D. Lukacs, "Zone Electrophoresis in Open-Tubular Glass Capillaries," Analytical Chemistry, Vol. 53, No. 8, 1981, pp. 1298-1302. doi: $10.1021 / \mathrm{ac} 00231 \mathrm{a} 037$

[4] J. Wang, A. Escarpa, M. Pumera and J. Feldman, "Capillary Electrophoresis-Electrochemistry Microfluidic System for the Determination of Organic Peroxides," Journal of Chromatography A, Vol. 952, No. 1-2, 2002, pp. 249254. doi:10.1016/S0021-9673(02)00075-4

[5] L. D. Bo, P. Mazzucchelli and A. Marzo, "Highly Sensitive Bioassay of Lidocaine in Human Plasma by HighPerformance Liquid Chromatography-Tandem Mass Spectrometry," Journal of Chromatography A, Vol. 854, No. 1-2, 1999, pp. 3-11. doi:10.1016/S0021-9673(99)00415-X

[6] E. Chan and P. Ho, "Enantiomeric Separation of Tramadol Hydrochloride and Its Metabolites by Cyclodextrin-Mediated Capillary Zone Electrophoresis," Journal of Chromatography B, Vol. 707, No. 1-2, 1998, pp. 287-294. doi:10.1016/S0378-4347(97)00605-1

[7] M. Pospíšilová, M. Polášek and V. Jokl, "Determination of Tramadol in Various Dosage Forms by Capillary Isotachophoresis," Journal of Pharmaceutical and Biomedical Analysis, Vol. 18, No. 4-5, 1998, pp. 777-783. doi:10.1016/S0731-7085(98)00270-2

[8] S. Rudaz, S. Cherkaoui, P. Dayer, S. Fanali and J.-L. Veuthey, "Simultaneous Stereoselective Analysis of Tramadol and Its Main Phase I Metabolites by On-Line Capillary Zone Electrophoresis-Electrospray Ionization Mass Spectrometry," Journal of Chromatography A, Vol. 868, No. 2, 2000, pp. 295-303.

doi:10.1016/S0021-9673(99)01257-1

[9] U. B. Soetebeer, M.-O. Schierenberg, H. Schulz, G. Grünefeld, P. Andresen and G. Blaschke, "Assay of Tramadol in Urine by Capillary Electrophoresis Using Laser-Induced Native Fluorescence Detection," Journal of Chromatography B, Vol. 745, No. 2, 2000, pp. 271-278. doi:10.1016/S0378-4347(00)00280-2

[10] A. W. Knight and G. M. Greenway, "Occurrence, Mechanisms and Analytical Applications of Electrogenerated Chemiluminescence. A Review," Analyst, Vol. 119, No. 5, 1994, pp. 879-890. doi:10.1039/an9941900879

[11] X. Wang and D. R Bobbitt, "In Situ Cell for Electrochemically Generated $\mathrm{Ru}(\mathrm{bpy})_{3}^{3+}$-Based Chemiluminescence Detection in Capillary Electrophoresis," Analytica Chimica Acta, Vol. 383, No. 3, 1999, pp. 213-220. doi:10.1016/S0003-2670(98)00811-3

[12] D. R. Bobbitt, W. A Jackson and H. P. Hendrickson, "Chemiluminescent Detection of Amines and Amino Ac- ids Using in Situ Generated Ru(bpy) ${ }_{3}^{3+}$ Following Separation by Capillary Electrophoresis," Talanta, Vol. 46, No. 4, 1998, pp. 565-572. doi:10.1016/S0039-9140(97)00318-4

[13] G. A Forbes, T. A Nieman and J. V Sweedler, "On-Line Electrogenerated $\mathrm{Ru}(\mathrm{bpy})_{3}^{3+}$ Chemiluminescent Detection of $\beta$-Blockers Separated with Capillary Electrophoresis," Analytica Chimica Acta, Vol. 347, No. 3, 1997, pp. 289-293. doi:10.1016/S0003-2670(97)00157-8

[14] J. A. Dickson, M. M. Ferris and R. E. Milofsky, "Tris (2,2'-bipyridyl)ruthenium(III) as a Chemiluminescent Reagent for Detection in Capillary Electrophresis," Journal of High Resolution Chromatography, Vol. 20, No. 12, 1997, pp. 643-646. doi:10.1002/jhrc.1240201205

[15] H. P Hendrickson, P. Anderson, X. Wang, Z. Pittman and D. R. Bobbitt, "Compositional Analysis of Small Peptides Using Capillary Electrophoresis and $\mathrm{Ru}(\mathrm{bpy})_{3}^{3+}$-Based Chemiluminescence Detection," Microchemical Journal, Vol. 65, No. 2, 2000, pp. 189-195. doi:10.1016/S0026-265X(00)00052-7

[16] X. Wang and D. R. Bobbitt, "Electrochemically Generated $\mathrm{Ru}(\mathrm{bpy})_{3}^{3+}$-Based Chemiluminescence Detection in Micellar Electrokinetic Chromatography," Talanta, Vol. 53, No. 2, 2000, pp. 337-345. doi:10.1016/S0039-9140(00)00494-X

[17] W. D. Cao, J. F. Liu, H. B. Qiu, X. R. Yang and E. K. Wang, "Simultaneous Determination of Tramadol and Lidocaine in Urine by End-Column Capillary Electrophoresis with Electrochemiluminescence Detection," Electroanalysis, Vol. 14, No. 22, 2002, pp. 1571-1576. doi:10.1002/1521-4109(200211)14:22<1571::AID-ELAN 1571>3.0.CO;2-X

[18] Y. B. Zu and A. J. Bard, "Electrogenerated Chemiluminescence. 66. The Role of Direct Coreactant Oxidation in the Ruthenium Tris(2,2')bipyridyl/Tripropylamine System and the Effect of Halide Ions on the Emission Intensity," Analytical Chemistry, Vol. 72, No. 14, 2000, pp. 32233232. doi:10.1021/ac000199y

[19] M. M. Richter, "Electrochemiluminescence (ECL)," Chemical Reviews, Vol. 104, No. 6, 2004, pp. 3003-3036. doi:10.1021/cr020373d

[20] J. F. Liu, W. D. Cao, X. R. Yang and E. K. Wang, "Determination of Diphenhydramine by Capillary Electrophoresis with Tris(2,2'-bipyridyl)ruthenium(II) Electrochemiluminescence Detection," Talanta, Vol. 59, No. 3, 2003, pp. 453-459. doi:10.1016/S0039-9140(02)00535-0

[21] J. L. Yan, J. F. Liu, W. D. Cao, X. H. Sun, X. R. Yang and E. K. Wang, "Determination of Benzhexol Hydrochloride by Capillary Zone Electrophoresis with an EndColumn Electrochemiluminescence Detection," Microchemical Journal, Vol. 76, No. 1-2, 2004, pp. 11-16. doi:10.1016/j.microc.2003.10.003

[22] X. H. Sun, J. F. Liu, W. D. Cao, X. R. Yang, E. K. Wang and Y. S. Fung, "Capillary Electrophoresis with Electrochemiluminescence Detection of Procyclidine in Human Urine Pretreated by Ion-Exchange Cartridge," Analytica 
Chimica Acta, Vol. 470, No. 2, 2002, pp. 137-145. doi:10.1016/S0003-2670(02)00780-8

[23] X. C. Zhao, T. Y. You, J. F. Liu, X. H. Sun, J. L. Yan, X. R. Yang and E. K. Wang, "Drug-Human Serum Albumin Binding Studied by Capillary Electrophoresis with Electrochemiluminescence Detection," Electrophoresis, Vol. 25, No. 20, 2004, pp. 3422-3426. doi:10.1002/elps.200305930

[24] W. D. Cao, X. R. Yang and E. K. Wang, "Determination of Reserpine in Urine by Capillary Electrophoresis with Electrochemiluminescence Detection," Electroanalysis, Vol. 16, No. 3, 2004, pp. 169-174. doi:10.1002/elan.200402777

[25] S. Gan, R. Ismail, W. W. Adnan and Z. Wan, "Method Development and Validation of a High-Performance Liquid Chromatographic Method for Tramadol in Human Plasma Using Liquid-Liquid Extraction," Journal of Chromatography B, Vol. 772, No. 1, 2002, pp. 123-129. doi:10.1016/S1570-0232(02)00065-X

[26] M.-R. Rouini, Y. H. Ardakani, F. Soltani, H. Y. AboulEnein and A. Foroumadi, "Development and Validation of a Rapid HPLC Method for Simultaneous Determination of Tramadol, and Its Two Main Metabolites in Human Plasma," Journal of Chromatography B, Vol. 830, No. 2, 2006, pp. 207-211. doi:10.1016/j.jchromb.2005.10.039
[27] C. Moore, S. Rana and C. Coulter, "Determination of Meperidine, Tramadol and Oxycodone in Human Oral Fluid Using Solid Phase Extraction and Gas Chromatography-Mass Spectrometry," Journal of Chromatography $B$, Vol. 850, No. 1-2, 2007, pp. 370-375. doi:10.1016/i.jchromb.2006.12.008

[28] S. N. Ding, J. J. Xu, W. J. Zhang and H. Y. Chen, "Tris(2,2'-bipyridyl)ruthenium(II)-Zirconia-Nafion Composite Modified Electrode Applied as Solid-State Electrochemiluminescence Detector on Electrophoretic Microchip for Detection of Pharmaceuticals of Tramadol, Lidocaine and Ofloxacin," Talanta, Vol. 70, No. 3, 2006, pp. 572-577. doi:10.1016/j.talanta.2006.01.017

[29] Y. H. Ardakani and M.-R. Rouini, "Improved Liquid Chromatographic Method for the Simultaneous Determination of Tramadol and Its Three Main Metabolites in Human Plasma, Urine and Saliva," Journal of Pharmaceutical and Biomedical Analysis, Vol. 44, No. 5, 2007, pp. 1168-1173. doi:10.1016/j.jpba.2007.04.012

[30] E. Garrido, J. Garrido, F Borges and C Delerue-Matos, "Development of Electrochemical Methods for Determination of Tramadol-Analytical Application to Pharmaceutical Dosage Forms," Journal of Pharmaceutical and Biomedical Analysis, Vol. 32, No. 4-5, 2003, pp. 975-981. doi:10.1016/S0731-7085(03)00199-7 